\title{
Desain Kapal Pengolah Ikan sebagai Bahan Baku Pembuatan Tepung di Perairan Lamongan
}

\author{
Muhammad Fajar Indra Afrianta, dan Hesty Anita Kurniawati \\ Departemen Teknik Perkapalan, Fakultas Teknologi Kelautan, Institut Teknologi Sepuluh Nopember (ITS) \\ Jl. Arief Rahman Hakim, Surabaya 60111 Indonesia \\ e-mail: tita@na.its.ac.id
}

\begin{abstract}
Abstrak-Perairan Utara Laut Jawa mempunyai potensi perikanan yang cukup besar. Dari data yang diperoleh dari Dinas Perikanan dan Kelautan Provinsi Jawa Timur tahun 2005-2015 banyak sekali jenis ikan pelagis dan demersal yang memiliki gizi yang tinggi didapatkan dari lokasi ini. Kabupaten Lamongan salah satu penghasil ikan terbesar di Jawa Timur. Akan tetapi, masih sedikit ikan yang diolah. Oleh sebab itu perlu ada pengembangan kapal ikan untuk mendapatkan kapal ikan yang mampu memberi nilai tambah terhadap tangkapan ikan. Cara yang dapat ditempuh adalah dengan menambah fungsi kapal sebagai kapal pengolah ikan sehingga nilai jual hasil tangkapan akan bertambah. Tujuan dari Studi ini adalah untuk mendesain sebuah kapal pengolah ikan yang digunakan untuk perairan di Lamongan. Kapal ikan ini akan mengolah hasil tangkapan ikan kurisi yang diperoleh dari para nelayan di atas kapal dengan hasil akhir tepung ikan yang dikemas pada karung. Penentuan kapasitas muatan kapal ikan ditentukan dari hasil tangkapan ikan kurisi per tahun. Kemudian dilakukan perhitungan teknis yang memenuhi regulasi. Ukuran utama yang didapatkan adalah Lpp $=27 \mathrm{~m}, \mathrm{~B}=4.20 \mathrm{~m}, \mathrm{~T}=1.65 \mathrm{~m}, \mathrm{H}=2.4 \mathrm{~m}, \mathrm{Cb}=0.71$, dan Vs = 7 knot. Dari ukuran utama tersebut kemudian dibuat gambar Rencana Garis dan gambar Rencana Umum. Analisis ekonomis yang dilakukan adalah memperhitungkan biaya pembangunan, biaya operasional, dan BEP.
\end{abstract}

Kata Kunci-Kapal Ikan, Pengolah Ikan, Lamongan, Tepung.

\section{PENDAHULUAN}

I NDONESIA dengan panjang pantai mencapai $95.181 \mathrm{~km}$ dengan luas wilayah laut 5,4 juta $\mathrm{km}^{2}$, adalah negara kepulauan terbesar di dunia karena memiliki luas laut dan jumlah pulau yang besar. Total luas teritorial Indonesia mendominasi sebesar 7,1 juta $\mathrm{km}^{2}$. Potensi tersebut menempatkan Indonesia sebagai negara yang dikaruniai sumber daya kelautan yang besar termasuk kekayaan keanekaragaman hayati dan non hayati kelautan terbesar. Sehingga membuat membuat wilayah laut Indonesia kaya akan hasil laut yang melimpah. Menurut data potensi sumber daya perikanan yang diterbitkan Kementerian Kelautan dan Perikanan 2015, Indonesia merupakan negara terbesar kedua penghasil ikan tangkap laut setelah Cina. Per tahun, produksi ikan yang dihasilkan mampu mencapai 5 juta ton. Namun, sampai sekarang mayoritas nelayan, terutama nelayan buruh, masih hidup dalam kubangan kemiskinan

Lamongan dikenal sebagai penghasil ikan terbesar di Jawa Timur. Nilai produksi perikanan di Kabupaten Lamongan sepanjang tahun 2015 mencapai Rp 2.066.126.188.437. Nilai produksi itu meliputi, dari perairan umum sebesar Rp
53.963.637 dari produksi perikanantangkap menghasilkan Rp 940.041.822.000, dan nilai produksi perikanan budidaya sebesar Rp 1.126.030.402.800. Namun produksi yang besar itu tidak serta merta menunjukkan peningkatan kesejahteraan nelayan. Ikan yang dihasilkan sebagian besar dijual begitu saja tidak ada nilai tambah dan kualitas produksi olahan kurang

Agar nelayan bisa sejahtera, besarnya produksi ini harus diimbangi dengan nilai jual yang tinggi melalui pemberian nilai tambah dengan diolah terlebih dahulu. Meski sebagai produsen ikan terbesar di Jawa Timur, namun perusahaan yang fokus ke pengelolaan ikan di Lamongan ternyata sangat minim. Karena minimnya pengelolaan ikan, kesejahteraan petani masih sangat memperihatinkan

Dari latar belakang di atas penulis akan mendesain sebuah kapal pengolah ikan yang akan beroperasi di perairan Lamongan. kapal ini nantinya akan mendatangi kapal-kapal nelayan dan mengolah ikan yang siap untuk diproses menjadi bahan baku pembuatan tepung ikan. Kapal yang didesain penulis diharapkan dapat menjadi terobosan baru dalam industry untuk meningkatkan kesejahteraan para nelayan.

\section{TINJAUAN PUSTAKA}

\section{A. Morfologi dan Klasifikasi Ikan Kurisi}

Ikan kurisi memiliki bentuk badan bulat memanjang, tertutup sisik yang mudah tanggal atau lepas. Kepala tanpa duri dan bagian depannya tidak bersisik. Sirip punggung berjari-jari keras 10 dan 9 lemah. Jari-jari keras pertama dan kedua tumbuh memenjang seperti serabut, demikian juga jarijari teratas lembaran sirip ekornya. Sirip dubur berjari-jari keras 3 dan 7 jari-jari lemah. Warna kepala dan gigir punggung kemerahan. Cambuk pada sirip punggung maupun ekornya berwarna kuning. Sirip punggung abu-abu keunguan dengan warna kuning ditengah-tengahnya demikian juga sirip dubur. Sirip ekor sedikit kegelapan. Sirip perut dan dada putih sedikit kecoklatan. Ukuran ikan kurisi dapat mencapai panjang $25 \mathrm{~cm}$, umumnya $12-18 \mathrm{~cm}[1]$.

Taksonomi ikan kurisi adalah sebagai berikut:

$\begin{array}{ll}\text { Filum } & : \text { Chordata } \\ \text { Sub Filum } & : \text { Vertebrata } \\ \text { Kelas } & : \text { Pisces } \\ \text { Sub Kelas } & : \text { Teleosei } \\ \text { Ordo } & : \text { Percomorphi } \\ \text { Sub Ordo } & : \text { Percoidae } \\ \text { Famili } & : \text { Nemipteridae }\end{array}$


Genus : Nemipterus

Spesies : : Nemipterus sp. (Bloch 1791)

Nama Inggris : Threadfin Bream

Nama Lokal : Ikan Kurisi

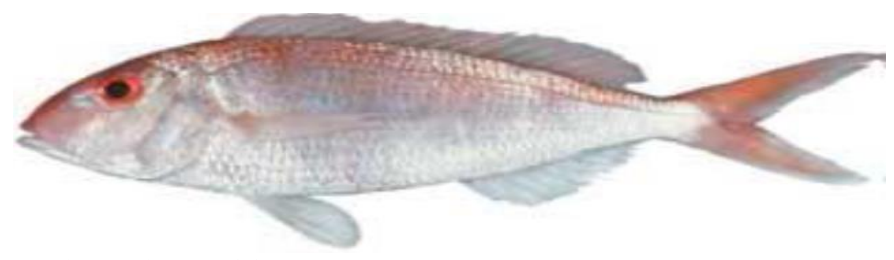

Gambar 1. Ikan Kurisi

\section{B. Tepung Ikan}

Ikan merupakan sumber protein hewani yang dimanfaatkan semaksimal mungkin untuk memenuhi kebutuhan manusia dan untuk meningkatkan kesejahteraan manusia. Tepung ikan adalah suatu produk bubuk kering yang diolah dari ikan utuh atau dari limbah olahan ikan yang tidak dapat diterima untuk dikonsumsi manusia[2].

Kandungan protein tepung ikan yang relatif tinggi merupakan salah satu bahan baku sumber protein hewani yang dibutuhkan untuk komposisi makanan ternak dan ikan[3]. Protein hewani yang terkandung dalam tepung ikan tersusun oleh asam-asam amino essensial yang kompleks, diantaranya asam amino lisin dan methionin, disamping itu juga mengandung mineral kalsium dan fosfor, serta vitamin B kompleks, khususnya vitamin B12[4].

\section{Gambaran Umum Kapal Ikan}

Menurut (Fyson, 1985), Kapal perikanan secara umum terdiri dari: kapal penangkap ikan, kapal pengangkut hasil tangkapan, kapal survei, kapal latih dan kapal pengawas perikanan.

1. Kapal penangkap ikan adalah kapal yang dikonstruksi dan digunakan khusus untuk menangkap ikan sesuai dengan alat penangkap dan teknik penangkapan ikan yang digunakan termasuk menampung, menyimpan dan mengawetkan.

2. Kapal Pengangkut Hasil Tangkapan adalah kapal yang dikonstruksi secara khusus, dilengkapi dengan palkah khusus yang digunakan untuk menampung, menyimpan, mengawetkan dan mengangkut ikan hasil tangkapan.

3. Kapal Survei adalah kapal yang dikonstruksi khusus untuk melakukan kegiatan survei perikanan dan kelautan.

4. Kapal Latih adalah kapal yang dikonstruksi khusus untuk pelatihan penangkapan ikan.

5. Kapal Pengawas Perikanan perikanan adalah kapal yang dikonstruksi khusus untuk kegiatan pengawasan kapalkapal perikana[5].

Sedangkan kapal ikan yang akan dibahas dalam studi ini adalah kapal ikan yang fungsinya untuk mengolah ikan.

\section{Proses Pengolahan Ikan.}

Pengolahan tepung ikan dengan menggunakan bahan baku berlemak tinggi, harus didahului dengan perebusan. Perebusan yang tidak sempurna akan menyebabkan protein menggumpal. Oleh karena itu, perebusan harus dilakukan secara sempurna atau dihentikan setelah mendidih selama kurang lebih 5 menit. Jika perebusan sempurna, kandungan air hasil pengepresan dapat mencapai 50\% - 55\%. Selama perebusan, sel yang mengandung lemak akan pecah, sehingga diperoleh hasil sampling berupa minyak ikan (setelah dipisahkan dari airnya). Setelah pengepresan, cairan akan terbuang $\pm 20 \%$ bagian dari padatan ikan. Ikut terbuangnya bagianpadatan tersebut akan menyebabkan kualitas tepung ikan yang dihasilkan menjadi rendah[4].

\section{TINJAUAN DAERAH OPERASIONAL}

\section{A. Tinjauan Umum Daerah}

Pantai Utara Laut Jawa merupakan daerah yang dikelilingi oleh sebagian dari kabupaten maupun kota yang ada di Jawa Timur, diantaranya adalah Kabupaten Tuban, Lamongan, Gresik, Bangkalan, Sampang, Pamekasan, Sidoarjo, Pasuruan, Probolinggo, Situbondo, Kota Surabaya, Kota Pasuruan dan Kota Probolinggo. Sedangakan sungai-sungai penting bermuara ke Laut jawa mayoritas berada pada daerah-daerah yang telah disebutkan sebelumnya antara lain :Sungai bengawan solo yang bermuara di ujung pangkah dan mengare, Kali lamong yang bermuara di Gresik serta Kali Brantas yang bermuara di Surabaya.

Kabupaten Lamongan adalah sebuah kabupaten di Provinsi Jawa Timur, Indonesia. Ibu kotanya adalah Lamongan. Kabupaten ini berbatasan dengan Laut Jawa di utara, Kabupaten Gresik di timur, Kabupaten Mojokerto dan Kabupaten Jombang di selatan, serta Kabupaten Bojonegoro dan Kabupaten Tuban di barat. Pusat pemerintahan Kabupaten Lamongan terletak $50 \mathrm{~km}$ sebelah barat Kota Surabaya, ibu kota Provinsi Jawa Timur. Kabupaten Lamongan merupakan salah satu wilayah yang masuk dalam kawasan metropolitan Surabaya, yaitu Gerbangkertosusila.

\section{B. Klimatologi}

Aspek klimatologi ditinjau dari kondisi suhu dan curah hujan. Keadaan iklim di Kabupaten Lamongan merupakan iklim tropis yang dapat dibedakan atas 2 (dua) musim, yaitu musim penghujan dan musim kemarau. Curah hujan tertinggi terjadi pada bulan Desember sampai dengan bulan Maret, sedangkan pada bulan-bulan lain curah hujan relatif rendah. Rata-rata curah hujan pada Tahun 2010 dari hasil pemantauan 25 stasiun pengamatan hujan tercatat sebanyak $2.631 \mathrm{~mm}$ dan hari hujan tercatat 72 hari. Pasang Surut dan Gelombang.

\section{Dermaga Bongkar Muat dan Tambat}

Untuk menunjang proses perencanaan kapal ikan, dermaga bongkar muat dan tambat merupakan salah satu faktor yang berpengaruh terhadap besar kecilnya kapal yang dapat drancang. Dermaga yang mempunyai panjang, lebar, dan sarat perairan yang lebih kecil dari data-data panjang, lebar, dan sarat kapal, maka dermaga tersebut tidak akan dapat disinggahi oleh kapal tersebut. Oleh karena itu sangatlah penting dalam melakukan proses perencanaan kapal ikan, peneliti harus menentukan dermaga mana yang dapat disinggahi oleh kapal yang akan dirancang. Untuk penelitian kali ini, peneliti akan merencanakan kapal yang beroperasi di perairan Lamongan, 
dengan dermaga bongkar muat dan tambat adalah pelabuhan BronSdong.

\section{Alur Pelayaran Kapal Ikan}

Kapal ikan dalam Studi ini tidak menangkap ikan, hanya mengolah ikan. Ikan didapatkan dengan menghampiri kapal kapal para nelayan. Ikan yang sudah didapatkan dari kapal nelayan kemudian disimpan dan diolah menjadi tepung.

Usaha penangkapan ikan laut di Kabupaten Lamongan terpusat di Perairan Laut Utara Jawa. Lamongan memiliki 5 (lima) Tempat Pendaratan Ikan (TPI), yaitu mulai dari arah timur ke barat (Weru, Kranji, Brondong, Labuhan dan Lohgung).

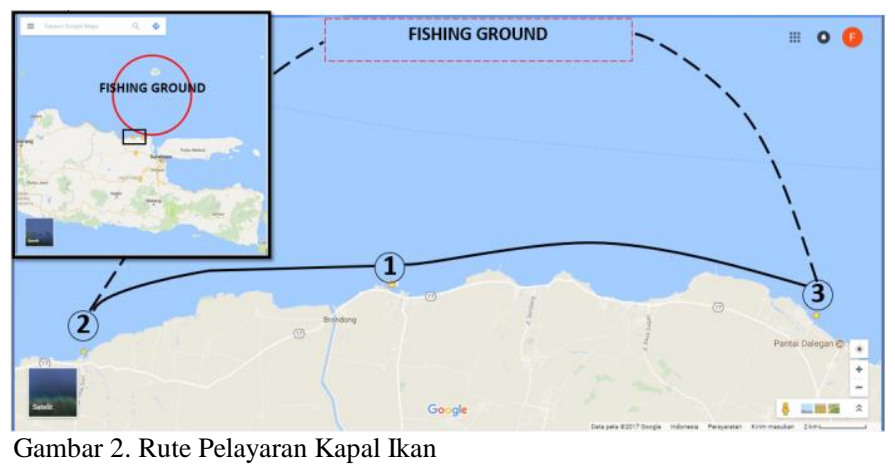

Gambar 2 adalah rute pelayaran kapal ikan. Pada gambar tersebut, angka 1 adalah PPN Brondong yang merupakan titik awal kapal beroperasi. Angka 2 adalah letak TPI Lohgung dan angka 3 adalah TPI Weru. Diasumsikan jarak terjauh ke fishing ground adalah 100 mil dan daerah fishing ground adalah lingkaran merah. Adapun perencanaan rute pelayaran yaitu :

Rute $1: 1$ - fishing ground -1

Rute 2: $1-2$-fishing ground -1

Rute $3: 1-3$-fishing ground -1

Rute $4: 1-2$-fishing ground $-3-1$

\section{E. Potensi Perikanan}

Wilayah Kabupaten Lamongan yang mempunyai batas fisik langsung dengan garis pantai merupakan lokasi yang berpotensi dapat diandalkan dalam perekonomian wilayah dalam hal pengembangan budidaya ikan dan pendapatan dalam sektor perikanan laut, dimana saat ini juga didukung oleh keberadaan Pelabuhan Perikanan Nusantara Brondong yang mempunyai skala pelayanan regional. Selain potensi perairan laut terdapat beberapa wilayah Kabupaten Lamongan yang mempunyai potensi perairan tambak, dengan potensi andalannya berupa produksi bandeng dan udang. Sektor perikanan tangkap yang ada di Kabupaten Lamongan memiliki potensi sumber daya manusia yang bekerja sebagai nelayan sebanyak 15.099 jiwa, dengan didukung jumlah armada tangkap \pm 5.487 unit perahu.

\section{ANALISIS TEKNIS DAN PEMBAHASAN}

\section{A. Proses Pengolahan Ikan di Kapal}

1. Penerimaan Bahan Baku

Bahan baku didapatkan dari kapal-kapal nelayan dengan cara mendatanginya. Ikan diangkut ke kapal induk dengan menggunakan keranjang. Ikan yang sudah didapatlan kemudian dibawa ke dalam area pengolahan untuk dilakukan tahap penyiangan.

2. Penyiangan

Proses selanjutnya setelah ikan ditimbang dan dibersihkan adalah proses penyiangan yaitu pemotongan kepala dan pembuangan isi perut. Ikan di potong kepalanya menggunakan pisau stainless steel yang tajam. Proses pemotongan ini dilakukan di meja pemotongan kepala yang juga terbuat dari stainless steel sehingga tidak berkarat dan tidak mengkontaminasi bahan.

3. Penyimpanan Ikan

Ikan yang telah dilakukan penyiangan, ikan disimpan kedalam cool box sampai memenuhi kapasitas mesin pengolah tepung dan diberi es untuk menghambat ikan menjadi busuk. Cool box yang dipakai memiliki kapasitas 600 liter.

4. Pengolahan Ikan dengan Mesin

Tahap selanjutnya adalah ikan yang sudah terkumpul mencapai kapasitas mesin pengolah ikan, ikan dikeluarkan dari cool box dan dimasukkan ke dalam mesin pengolah tepung.

Tahap pengolahan yang dilakukan oleh mesin tersebut yaitu proses pemasakan, pressing, dan tahap akhir adalah proses pengeringan.

5. Pengemasan

Hasil akhir yang dihasilkan mesin ini adalah berupa bubuk tepung. Kemudian, tepung yang dihasilkan dikemas dengan menggunakan karung dengan kapasitas $50 \mathrm{~kg}$.

\section{B. PenentuanUkuran Utama Kapal}

Dalam penentuan ukuran utama kapal pada Jurnal ini dipengaruhi oleh beberapa faktor. Adapun faktor-faktor yang digunakan dalam penentuan ukuran utama kapal yaitu penentuan trip kapal dan hasil tangkapan ikan kurisi yang nantinya digunakan untuk menentukan kapasitas ruang muat.

1. Penentuan Kapasitas Muatan

a. Hasil produksi ikan Kurisi di Kab. Lamongan

Tabel 1.

Data tangkapan Ikan Kurisi

\begin{tabular}{cccc}
\hline \hline Tahun & Jumlah (ton) & Tahun & Jumlah (ton) \\
\hline 2005 & 168.9 & 2012 & 79 \\
2006 & 202.7 & 2013 & 178.2 \\
2007 & 2181 & 2014 & 1073.5 \\
2008 & 1639.1 & 2015 & 2646 \\
2009 & 759.7 & 2016 & 1599.88 \\
2010 & 4926.7 & 2017 & 1460.56 \\
2011 & 97.3 & & \\
\hline \hline
\end{tabular}


Data yang didapatkan dari Dinas Perikanan dan Kelautan adalah tahun 2005-2015, sedangkan data 2016-2017 dilakukan metode Forecasting (peramalan). Data yang digunakan adalah tahun 2017 sebagai acuan penentuan kapasitas muatan kapal ikan sebesar 1460.56 ton[6].

b. Perkiraan Trip yang direncanakan adalah sebagai berikut :

- Kapal beroperasi dengan kecepatan 7 knots. Dikarenakan fishing ground yang selalu berpindah tempat maka radius jarak operasi diasumsikan 100 mil. Waktu yang dibutuhkan untuk berangkat ke jarak paling jauh adalah

- Berangkat : :0.6 hari

- Pulang : 0.6 hari

- Waktu operasi kapal : 17 hari

- Bongkar muat $\quad: 1$ hari

- Total : 18 hari

Sehingga jumlah trip yang dilakukan selama setahun adalah $365 / 18=20.2778$ kali.

Koreksi trip :

- Musim paceklik : 60 hari

- Docking kapal : 15 hari

- Bulan purnama : 24 hari

- Libur crew : 7 hari

- Total : 106 hari

Trip koreksi selama kapal beroperasi 106/18 $=5.8889$.

Sehingga trip yang direncanakan dalam setahun adalah 20.2778-5.8889 = 14 kali

2. Penentuan ukuran utama

Tepung akan dikemas dengan menggunakan karung yang berukuran 800x500 dengan kapsitas $50 \mathrm{~kg}$. Jumlah karung yang dibutuhkan adalah 52.1628/0.05 = 1044 karung.

Stowage factor ikan dalam es adalah $0.5 \mathrm{ton} / \mathrm{m} 3$ dan volume ikan menjadi 5.79586/0.5 = $11.5917 \mathrm{~m} 3$. Box yang digunakan memiliki kapasitas 600 liter. Jumlah box yang direncanakan 18 box dan ditaruh dibawah geladak. Ukuran per box adalah 1235x1000x750 mm.

Panjang, lebar, dan tinggi kapal disesuaikan dengan peletakkan cool box dan karung tepung. Akhirnya ukuran utama kapal awal yang didapatkan agar memenuhi jumlah muatan dan peletakkan ruangan-ruangan adalah $\mathrm{Lpp}=27 \mathrm{~m}, \mathrm{~B}$ $=4.2 \mathrm{~m}, \mathrm{H}=2.4 \mathrm{~m}, \operatorname{Dan} \mathrm{T}=1.65 \mathrm{~m}$

\section{Perhitungan Koefisien Bentuk Kapal}

Setelah didapatkan ukuran utama kapal, langkah selanjutnya yang dilakukan adalah melakukan perhitungan awal. Perhitungan awal meliputi pemeriksaan rasio ukuran, perhitungan froud number, perhitungan coefficient $(\mathrm{Cb}, \mathrm{Cm}$, $\mathrm{Cp}$, dan Cwp) serta displacement dan volume displacement.

1. Pemeriksaan Rasio Ukuran Utama yang dapat dilihat pada Tabel 2
Tabel 2.

Pemeriksaan Rasio Ukuran Utama

\begin{tabular}{ccccc}
\hline \hline & Value & Status & \multicolumn{2}{c}{ Range } \\
\hline $\mathrm{L} / \mathrm{B}=$ & 6.43 & ok & Resistance & $3.5<\mathrm{L} / \mathrm{B}<10$ \\
$\mathrm{~L} / \mathrm{T}=$ & 16.36 & ok & Long. Strength & $10<\mathrm{L} / \mathrm{T}<30$ \\
$\mathrm{~B} / \mathrm{H}=$ & 1.75 & ok & Stability & \pm 1.88 \\
$\mathrm{~B} / \mathrm{T}=$ & 2.55 & ok & Stability & $1.8<\mathrm{B} / \mathrm{T}<5$ \\
$\mathrm{~T} / \mathrm{H}=$ & 0.69 & ok & Freeboard & \pm 0.73 \\
\hline \hline
\end{tabular}

2. Coefficient ukuran utama kapal

$$
\begin{array}{llll}
\mathrm{Fn} & =0.21 & \mathrm{Cm}=0.986 & \mathrm{Cp}=0.720 \\
\mathrm{Cb} & =0.71 & \mathrm{Cwp}=0.799 & \\
\nabla & =138.187 \mathrm{~m} 3 & \Delta=141.642 \text { ton }
\end{array}
$$

\section{Perhitungan Hambatan Kapal Total (Rt)}

Perhitungan hambatan total dilakukan dengan metode Holtrop \& Mennen[7].

$$
R T=1 / 2 \cdot p \cdot v 2 \cdot \operatorname{Stot}[C F(1+k)+C A]+R W / W \cdot W
$$

Koreksi untuk jalur pelayaran di Asia Timur sebesar 15\% 20\%). Sehingga, $R T=4.115600235 K N$

\section{E. Perhitungan Power dan Pemilihan Mesin Induk}

Setelah nilai hambatan total (RT) diketahui langkah selanjutnya adalah melakukan perhitungan power yang dibutuhkan untuk menggerakkan kapal.

Perhitungan BHP (Delivery Horse Power) menggunakan sumber Parametric Design chapter 11[8].

Sehingga, $\mathrm{BHP}=40.609 \mathrm{HP}$

$$
=30.2822978 \mathrm{KW}
$$

Spesifikasi mesin induk dapat dilihat pada Tabel 3.

Tabel 3.

Spesifikasi Mesin Induk

\begin{tabular}{cccccc}
\hline \hline \multicolumn{5}{c}{ Brand: Lombardini } \\
\hline Tipe & \multicolumn{5}{c}{$:$ LDW 2204 M (inboard) } \\
Power & $: 50 \mathrm{HP}$ & Berat & $: 232 \mathrm{~kg}$ & Lebar & $: 540 \mathrm{~mm}$ \\
Max HP & & & & & \\
Power & $: 36 \mathrm{KW}$ & Silinder & $: 4$ & Tinggi & $: 630 \mathrm{~mm}$ \\
Max Kw & $: 3000$ & Panjang & $: 926 \mathrm{~mm}$ & & \\
RPM & $: 300$
\end{tabular}

\section{F. Perhitungan Berat Kapal}

Berat kapal terdiri dari 2 komponen, yaitu komponen DWT (dead Weight tonnage) dan komponen LWT (Light Weight tonnage) seperti pada Tabel 4.

Tabel 4.

Total Berat DWT dan LWT

\begin{tabular}{cclc}
\hline \hline NO & Komponen Berat Kapal & Harga & Unit \\
\hline 1 & DWT & 96.918 & ton \\
2 & LWT & 31.984 & ton \\
& Total & 128.902 & ton \\
\hline \hline
\end{tabular}

\section{G. Perhitungan Freeboard}

Perhitungan lambung timbul kapal ikan menggunakan aturan Non-Convention Vessel Standart (NCVS) Indonesian Flagged yang dikeluarkan oleh Kementrian Perhubungan 
Republik Indonesia. Rekapitulasi perhitungan freeboard dapat dilihat pada Tabel 5[9].

Tabel 5.

Freeboard Hasil dari Perhitungan

\begin{tabular}{ccc}
\hline \hline Lambung Timbul & Nilai & Satuan \\
\hline Lambung Timbul yang Syaratkan & 0.15 & $\mathrm{~m}$ \\
Lambung Timbul Sebenarnya & 0.75 & $\mathrm{~m}$ \\
Kondisi & Diterima & \\
\hline \hline
\end{tabular}

\section{H. Perhitungan stabilitas}

Stabilitas merupakan salah satu kriteria yang harus dipenuhi pada proses desain kapal. Analisis stabilitas digunakan untuk mengetahui keseimbangan kapal secara melintang atau oleng pada beberapa kriteria kondisi pemuatan (Loadcase). Kriteria stabilitas yang digunakan adalah kriteria stabilitas untuk kapal jenis umum yang mengacu pada IMO [10]. Rekapitulasi perhitungan stabilitas dapat dilihat pada Tabel 6. dan Tabel 7.

Tabel 6.

Rekapitulasi Pehitungan Stabilitas Loadcase 1-4

\begin{tabular}{|c|c|c|c|c|c|c|c|c|}
\hline \multirow{2}{*}{ No. } & \multirow{2}{*}{ Criteria } & \multirow{2}{*}{ Value } & \multirow{2}{*}{ Unit } & \multicolumn{5}{|c|}{ Actual Condition } \\
\hline & & & & 1 & 2 & 3 & 4 & Status \\
\hline 1 & Area 0 to 30 & 3.151 & m.deg & 14.644 & 10.537 & 8.224 & 9.478 & Pass \\
\hline 2 & & 5.157 & m.deg & 24.948 & 18.534 & 14.621 & 16.639 & Pass \\
\hline 3 & Area 3 & 1.719 & m.deg & 10.304 & 7.997 & 6.398 & 7.161 & Pass \\
\hline 4 & Max GZ at 30 or greater & 0.2 & $\mathrm{~m}$ & 1.319 & 0.972 & 0.751 & 0.863 & Pass \\
\hline 5 & Ancle of mo & 25 & deg & 60 & 55.5 & 50.9 & 53.6 & Pass \\
\hline 6 & Initial GMt & 0.15 & $\mathrm{~m}$ & 1.921 & 1.311 & 1.006 & 1.183 & Pass \\
\hline
\end{tabular}

Tabel 7.

Perhitungan Stabilitas Loadcase 5-7

\begin{tabular}{|ccc|c|c|c|c|c|}
\hline \multirow{2}{*}{ No. } & \multirow{2}{*}{ Criteria } & \multirow{2}{*}{ Value } & \multirow{2}{*}{ Unit } & \multicolumn{5}{c}{ Actual Condition } \\
\cline { 5 - 9 } & & & $\mathbf{5}$ & $\mathbf{6}$ & $\mathbf{7}$ & Status \\
\hline $\mathbf{1}$ & Area 0 to 30 & 3.151 & $\mathrm{~m} . \mathrm{deg}$ & 9.061 & 7.838 & 7.723 & Pass \\
\hline $\mathbf{2}$ & Area 0 to 40 & 5.157 & $\mathrm{~m} . \mathrm{deg}$ & 15.99 & 13.954 & 13.766 & Pass \\
\hline $\mathbf{3}$ & Area 30 to 40 & 1.719 & $\mathrm{~m}$ deg & 6.929 & 6.117 & 6.043 & Pass \\
\hline $\mathbf{4}$ & Max GZ at 30 or greater & 0.2 & $\mathrm{~m}$ & 0.832 & 0.719 & 0.708 & Pass \\
\hline $\mathbf{5}$ & Angle of maximum GZ & 25 & $\mathrm{deg}$ & 53.6 & 51.8 & 53.6 & Pass \\
\hline $\mathbf{6}$ & Initial GMt & 0.15 & $\mathrm{~m}$ & 1.123 & 0.956 & 0.94 & pass \\
\hline
\end{tabular}

\section{Pembuatan Rencana Garis}

Setelah semua perhitungan selesai, langkah selanjutnya adalah pembuatan Rencana Garis atau Lines Plan. Lines Plan ini merupakan gambar pandangan atau gambar proyeksi badan kapal yang dipotong secara melintang (body plan), secara memanjang (sheer plan), dan vertikal memanjang (half breadth plan). Lines Plan berguna untuk mendapatkan desain kapal yang optimum, terutama desain ruang muat. Rencana Garis dapat dilihat pada Gambar 3.

\section{J. Pembuatan Rencana Umum}

Langkah pertama dalam menyelesaikan permasalahan rencana umum adalah menempatkan ruangan-ruangan utama beserta batas-batasnya terhadap lambung kapal dan bangunan atas. Adapun ruangan utama dimaksud adalah ruang muat, kamar mesin, tangki-tangki (bahan bakar, ballast, air tawar, dll), dan ruang pengolahan. Rencana umum dapat dililhat pada Gambar 4.

\section{K. Gambar 3D}

Pembuatan bentuk hull kapal mengacu pada ukuran utama dan lines plan yang sudah didapatkan. Untuk pembuatan gambar 3 dimensi ini dilakukan dengan dengan mengacu pada
General Arrangement. Desain 3 dimensi dari kapal ikan dapat dilihat pada Gambar. 4.

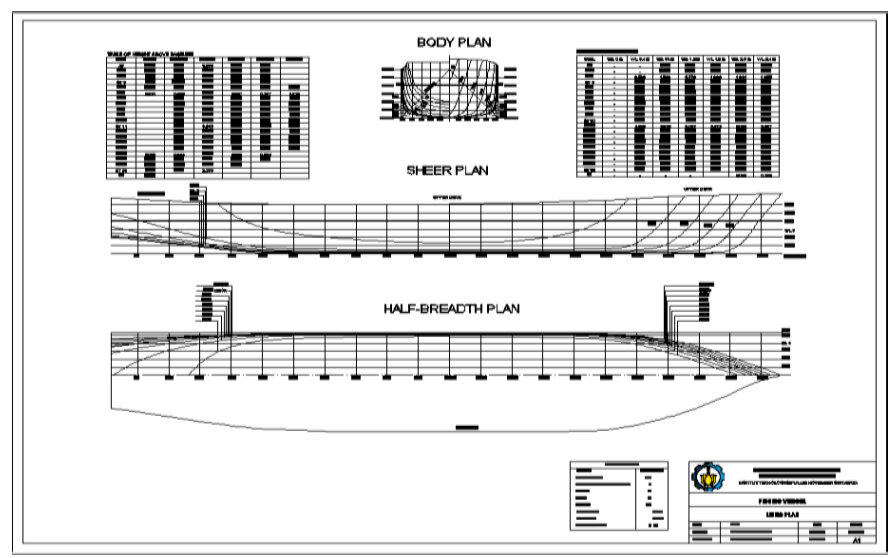

Gambar 3. Lines Plan

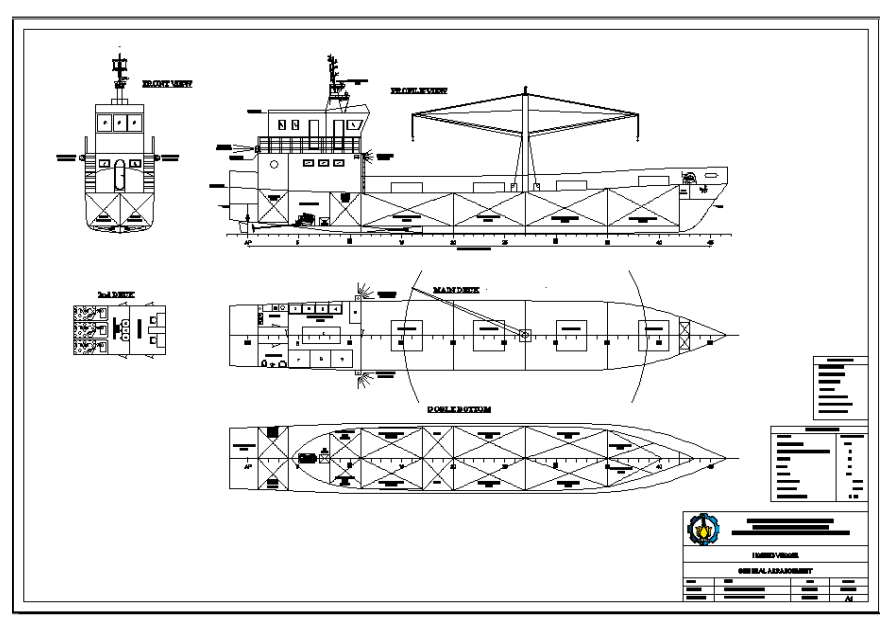

Gambar 4. General Arrangement

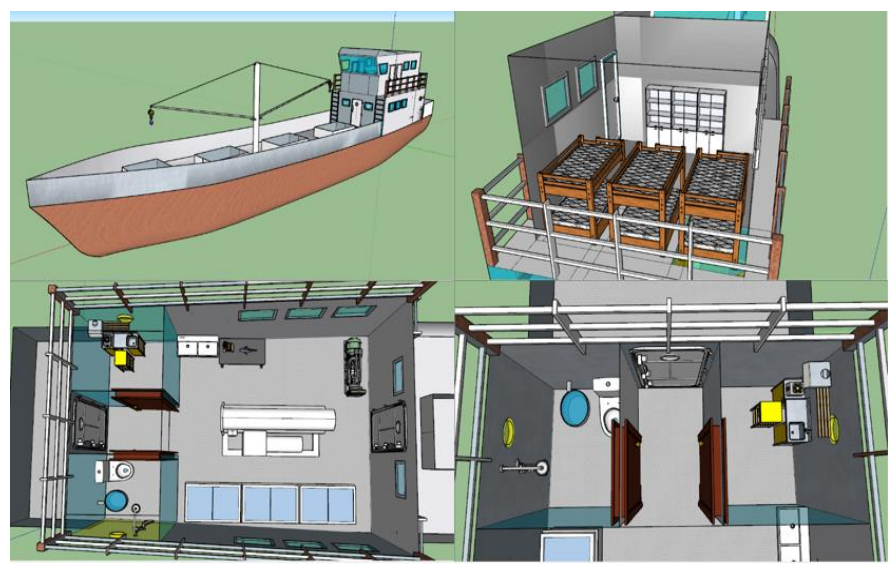

Gambar 5. Tiga Dimensi

\section{ANALISIS EKONOMIS}

A. Perhitungan Biaya Pembangunan

a. Biaya Pembangunan adalah Rp 1,747,849,836.80.

b. Koreksi Keadaan Ekonomi dan Kebijakan Pemerintah sebesar Rp 559,311,947.78.

c. Total Biaya Pembangunan adalah Rp 2,307,161,784.57 


\section{B. Perhitungan BEP}
a. Biaya Operasioanal sebesar Rp 7,820,836,091.79.
b. Perhitungan Pendapatan sebesar Rp11,246,294,181.82.
c. Keuntungan bersih sebesar Rp 48,205,224.55.
d. Estimasi BEP terjadi pada bulan ke 48 tahun ke-4.

\section{KESIMPULAN}

Setelah dilakukan percobaan dan penelitian maka kesimpulan dari studi ini adalah sebagai berikut:

1. Ukuran utama kapal penangkap dan pengoloah ikan yang sesuai dengan Perairan Lamongan, yaitu :

- Length Overall (LOA) $\quad: 29.05$ meter

- Length of Peendicular (LPP) : 27 meter

- Length of Waterline (LWL) : 28.08 meter

- Breadth (B) : 4.2 meter

- Draught $(\mathrm{T}) \quad: 1.65$ meter

-Depth (D) : 2.4 meter

- Service Speed (VS) : 7 Knots

2. Sistem pengolahan ikan menggunakan mesin pengolah tepung. Bahan baku diterima kemudian dilakukan penyiangan. Ikan yang sudah dilakukan penyiangan dimasukkan ke dalam mesin pengolah ikan untuk dijadikan tepung. Proses yang terjadi di dalam mesin pengolah tepung adalah pemasakan, pressing, dan pengeringan. Tepung yang dihasilkan dikemas dengan menggunakan karung.

3. Berdasarkan Analisis Ekonomis yang dilakukan, didapatkan hasil sebagai berikut:

- Biaya Investasi Kapal : : Rp 2,307,161,784.57

- Pinjaman dari Bank : : Rp 1,615,013,249.20

- Biaya operasional Kapal : Rp 7,820,836,091.79

- Keuntungan Bersih : : Rp 48,205,224.55

- Payback Period : Bulan Ke 48

4. Desain Lines Plan telah dibuat dan dilampirkan pada lampiran.

5. Desain General Arrangement telah dibuat dan dilampirkan pada lampiran.

6. Desain 3D telah dibuat dan dilampirkan pada lampiran.

\section{DAFTAR PUSTAKA}

[1] Astawan, M. (2004). Tetap Sehat dengan Produk Makanan Olahan. Solo: Tiga Serangkai.

[2] Ghaly, V. R. (2013). Fish Processing Wastes as a Potential Source of Preteins Amino Acid and Oils. J Microb Biochem Technol: A critical Review.

[3] E. Purnamasari, B. I. (2006). Potensi dan Pemanfaatan bahan baku Produk Tepung ikan. EPP Vol 3.

[4] Murtidjo, A. (2001). Beberapa Metode Pengolahan Tepung Ikan. Yogyakarta: Kanisius.

[5] Fyson, J. (1985). Design of Small Fishing Vessels. Farnham,England: Fishing News Books Ltd..

[6] Timur, D. K. (2005-2015). Laporan Tahunan Statistik Perikanan Tangkap di jawa Timur. Surabaya: Dinas Kelautan dan Perikanan Provinsi Jawa Timur.

[7] Lewis, E. V. (1988). Principles of Naval Architecture, Volume II Resistance, Propulsion, and Vibration. NJ: The Society of Naval Architects and Marine Engineers.

[8] Parsons, M.G. (2001). Parametric Design (Chapter 11). Michigan, University of Michigan.

[9] Kementrian Perhubungan. (2009). Non-Convention Vessel Standart (NCVS) Indonesian Flagged. Jakarta : Kementrian Perhubungan Republik Indonesia.
[10] International maritime Organization (IMO). (2008). Intact Stability Code, Intact Stability for All Types of Ships Covered by IMO Instruments. London, UK: IMO. 